\title{
Education Management in Knowledge Based Society
}

\section{Summary}

Europe is developing its "knowledge society". It passes from an economy based on traditional factors of production (land, labor, capital) to one in which the major components are information and knowledge. It is well known that the socio-economical and technological development has an important impact on the labor market in developed nations. So, more skills are needed and a flexible and dynamic labor supply. Nowadays, developed and developing nations are increasingly able to deliver high skills at low costs. This paper investigates the achievements of the education systems and the interdependences between education and welfare.

\section{Introduction}

Socio-economic and technological development have an important impact on the labor market in the industrialized countries. Higher skills, evaluated knowledge have a greater significance and imply a more flexible and dynamic labor supply. This process influences the balance between the supply and demand on the labor market and creates discrepancies between their various segments. In order to anticipate and diminish these discrepancies, information about the present and the future possible discrepancies on the labor market are required.

"Development of a global innovation society depends on the mobility and integration in all nations of people, knowledge and technologies. As science, technology, and economic progress become more global, international collaboration is indispensable to generate the talent and knowledge needed to find solutions to fundamental global challenges." 1

\footnotetext{
${ }^{*}$ Ph.D. Student, Academy of Economic Studies, Bucharest, Romania.

${ }^{1}$ St. Petersburg Declaration „,Education for Innovative Societies in the 21st Century”, July 2006.
} 
Analyzing and solving these problems at a regional level has the advantage that the social partners, the public recruitment and employment services, the regional and local administration, the education system cooperate in order to establish the equilibrium between regional labor supply and demand. There is nowadays a tendency of solving the mismatches labor market problems at a regional level, involving the local factors.

There are two ways of solving the regional labor market discrepancies (between the labor supply and demand): supplementary training and retraining process.

Europe is developing its "knowledge society". It passes from an economy based on traditional factors of production (land, labour, capital) to one in which the major components are information and knowledge. It is well known that the socio-economical and technological development has an important impact on the labor market in developed nations. So, more skills are needed and a flexible and dynamic labor supply. Nowadays, developed and developing nations are increasingly able to deliver high skills at low costs.

It is well-known that on Romanian labor market there are problems in recruiting the workers (because of the labor force ageing) and in such circumstances the supplementary training and the retraining process can reduce the lack of labor force qualification, if there exists simultaneously a deficit and excess on the labor market.

The workers with occupations in excess (for which the supply is greater than the demand) can enter the training and retraining programs, and this is not valid only for those who are currently employed. The reverse of the medal is that this process stimulates the participation for unemployed persons. This is not easy to be applied in practice, one of the reasons being that training is expensive and it will be an option for workers with occupations in excess, only if significant personal benefits are expected. Some of the occupations differ so much, that it seems impossible to fill in the lack of information through training programs. At a regional level, the recruitment personnel problems can be solved by attracting workers from other region. It would be ideally that this should be in realized without training efforts, and so the future costs may be lower and the individuals can perform the same occupations as until now, only on a different labor market.

\section{Solving the labor market discrepancies at a regional level}

In a traditional way, training the unemployed persons is often considered a policy addressed to the labor supply, in order to strengthen the labor market position for persons with a less-favorable one. As the training programs take time, the training policies will be more efficient if they focus on anticipating the future possible discrepancies. If these training policies would be based on the present labor market discrepancies, the unemployed persons who would participate at a training program might be confronted, at the end of it, with a new labor market situation: it might exists a supply excess precisely for the skills they just acquired.

The matching-mismatching problems between the labor supply and demand refer to various aspects (quantitative and qualitative ones):

- quantitative matching problems - when there are differences between the number of available workers on the labor market with certain skills and knowledge, on one 
hand, and the number of vacant jobs for which these workers have the adequate skills, on the other hand,

- qualitative matching problems - refer to the discrepancies between the skills type and level of the workers in the labor supply, on one hand, and the conditions (in terms of skill and knowledge) required for occupying the vacant jobs.

Solving these problems might depend on the usage of the training programs. We can distinguish between supplementary training programs (that can improve and diversify the workers' skills and knowledge in their own activity field), and retraining programs (that retrain the interested persons in another activity field). The supplementary training programs are efficient tools in reducing the qualitative labor market discrepancies, while the retraining programs are more efficient in diminishing (attenuating) the quantitative ones.

Before setting the training policies for a certain region, there must be studied the following aspects:

- if the existing mismatches type in a certain labor market segment is qualitative or quantitative one;

- on what labor market segments should the training activities focus, in order to reduce most efficiently the labor market discrepancies.

The scenario presented in this paper is based on the predicted labor market flows and not on the "stocks" notion. For the labor supply we used the "expected job openings" concept, in the next year, which refers to the number of jobs which are presumed to become vacant on the labor market, due to the expansion demand (employment growth) and replacement demand.

If the number of expected job-openings is lower than the number of job-seekers, than there is a labor supply shortage. On contrary, if the number of job-openings is greater than the number of job-seekers, then there is a labor supply excess.

Not all the job-seekers have the required skills, even if the job is in their specialty domain in which they were trained through the educational system. The educational-base is not the only factor which makes a job-seeker suitable for a certain job. In labor market discrepancies analysis one can make the difference between the suitable job-seekers, adequate skills and experience, and the less-suitable job-seekers, due to, perhaps, some personal reasons or due to the skill obsolescence. The last type of job-seekers are lesscompetitive than the first one.

The employers are interested in hiring the most suited job-seekers. Comparing the labor demand with the suitable labor supply, for each labor market segment it results a "future predicted recruitment problems - indicator", defined as:

$$
\operatorname{IFRP}_{i}=\frac{E_{i}+J O_{i}}{E_{i}+U_{i}^{S}}
$$

$E_{i}=$ the current number of employed persons in the labour market segment " $i$ ";

$U_{i}^{S}=$ the number of suitable job-seekers in the labor market segment " $i$ ";

$J O_{i}=$ the number of job openings in the labor market segment " $i$ ", which represents the sum between the expansion demand $\left(E D_{i}\right)$ and the replacement demand $\left(R D_{i}\right)$ : 


$$
J O_{i}=E D_{i}+R D_{i}
$$

The number of suitable job-seekers is composed of: the suitable unemployed jobseekers, at a certain moment (); respectively, the predicted number of school-leavers during the next year $\left(S L_{i}\right)$ :

$$
U_{i}^{S}=U_{i}^{1}+S L_{i}
$$

If there is a suitable job-seekers shortage on the labor market segment " $i$ ", the employers will recruit less-suitable job-seekers for a certain job, at a certain moment. These job-seekers might become more suitable if they participate to supplementary training activities.

A second statistical indicator, called "the mismatch-type indicator" $\left(I T M_{i}\right)$ shows to what degree less-suitable job-seekers are available to occupy the remaining job-openings:

$$
I T M_{i}=\frac{\max \left(J O_{i}-U_{i}^{S}, 0\right)}{U_{i}^{2}}
$$

$I T M_{i}$ is defined as a ratio between the predicted number of job-openings which can not be occupied by suitable job-seekers $\left(J O_{i}-U_{i}^{S}\right)$ and the number of less suitable jobseekers in the labor market segment " $i$ " $\left(U_{i}^{2}\right)$.

If $I F R P_{i}>1$, the denominator consists of the difference between the predicted number of job-openings in segment " $i$ " of labor market and the number of suitable job-seekers in the same segment. $I T M_{i}$ indicates the number of remaining job-vacancies in the segment " $i$ " per less suited job-seekers in that segment.

If $I F R P_{i}<1$, then there is no vacant jobs for less-suited job-seekers. When the denominator in (3) is zero, and so $I T M_{i}=0$, there is a sufficient supply for suitable jobseekers. So, the probability of hiring a less-suitable job-seeker is practically zero.

These statistical indicators allow us to characterize the discrepancies between supply and demand on various labor-market segments. There can be three situations:

1. Excess supply, when the number of suitable unemployed job-seekers is greater than the predicted number of job-openings $\left(I F R P_{i}<1\right)$. The less-suitable job-seekers' chances to become employed in their own specialty domain are small. Their perspectives, their situation on this labor market segment might improve through retraining activities.

2. Qualitative supply shortage, situation described s a suitable unemployed jobseekers shortage $\left(I F R P_{i}>1\right)$. There are sufficient less-suitable job-seekers, with a relevant educational background $\left(I T M_{i}<1\right)$. Because these job-seekers don't meet the required conditions, imposed by the employer for occupying a job, they can participate in supplementary training programs, as an efficient tool in reducing the discrepancies in this segment and in improving their situation and job-perspectives. Also, they will have to compete with the job-seekers in other labor-market segments

3. Quantitative supply shortage; it presumes both a suited and a less-suited job-seekers shortage, in this labor market segment $\left(I F R P_{i}>1\right.$ and $\left.I T M_{i}>1\right)$. In this case, too, the supplementary training would be an effective tool for improving the less-suited 
unemployed persons' perspectives on the labor market; but it isn't enough to reduce the matching problems in the concerned labor market segment. It is necessary to include in these programs and the unemployed persons from other labor market segments, in order to increase the suitable labor market.

It can appreciate that it is not always clear what is the most efficient training program type in reducing the labor market discrepancies. If a qualitative supply shortage is expected, then we can take action by:

- the supplementary training for the less-suited job-seekers on a certain labor market segment;

- the retraining process for the job-seekers from other labor market segments for which there is a supply excess. We presume that only the suited job-seekers from those labor market segments where there is a supply excess, can participate in retraining programs for other labor market segments. The motives for such an action are:

- training process for the suited job-seekers in those labor market segments where there is a labor supply shortage is not efficient;

- retraining process for the less-suited job-seekers on another labor market is considered as a great consumer of financial and time resources.

The supplementary training opportunities for the less suitable job-seekers are influenced by:

- IFRP of their own labor market segment (especially the denominator in the computing relation). In a situation described by a labor supply excess, there are few chances to improve the less-suited job-seekers perspectives on the labor market through supplementary training programs. The supplementary training programs are considered significant when $\operatorname{IFRP}_{i}>1$.

- The total number of less-suitable job-seekers on a certain labor market segment (the first term of the nominator). The greater the number of less-suited job-seekers, the more candidates for the supplementary training programs, and the worst become each unemployed person's job perspectives.

- The number of retrainable job-seekers existing in the excess labor supply in other labor market segments (the third term of the nominator). The job-seekers retraining availability is not considered significant, but the existence of a certain similarity between his information backgrounds obtained through educational system and the required skills for a certain job, on the concerned labor market segment. We define a "similarity index" that shows the competitive level between the job-seekers:

$$
S_{i j}=\frac{\sum_{b}\left(\frac{E_{i b}}{E_{b}}\right)\left(\frac{E_{j b}}{E_{b}}\right)}{\sqrt{\sum_{b}\left(\frac{E_{i b}}{E_{b}}\right)^{2} \sum_{b}\left(\frac{E_{j b}}{E_{b}}\right)^{2}}}
$$

$E_{i b}$ represents the total number of workers with educational type " $i$ " and occupation " $b$ "; $E_{b}$ represents the total number of employees with occupation " $b$ "; 
The similarity index measures the limit up to which two different educational types " $i$ " and " $j "$ are related to the same occupational domain. By definition, $S_{i j}$ takes values between 0 (there is no similarity) and 1 (perfect similarity).

\section{Educational indicators}

Many scientists consider that literate people have a better health and a higher socioeconomic status. The general measure used is literacy rate calculated as the percentage of the population 15 years and older who are literate (can read and write). The variation of literacy rate across countries is very high, from $51,98 \%$ for underdeveloped countries to $93,94 \%$ for developed ones. EU countries are regions with medium literacy rates $(97,33 \%)$.

Recent studies argue that correlations of education with health and socio-economic status may have more to do with the effects of schooling rather than literacy in general. So, school life expectancy and mean years of schooling are another two studied indicators.

School life expectancy shows the overall level of development of an educational system in terms of the number of years of education that a child can expect to achieve. Special attention is required in interpretation as long as relatively higher school life expectancy indicates greater probability for children to spend more years in education but also higher overall retention within the education system. The overall mean of school life expectancy is 12.31 years, much higher in developed countries then in developing or underdeveloped ones (15.02 years in developed countries versus 6.95 years in underdeveloped countries). For EU countries school life expectancy is 15.47 years.

Between school life expectancy and GDP per capita is a logarithmic dependency. For EU countries, $52,77 \%$ of the variation of school life expectancy is explained by the variation of GDP per capita.

Mean years of schooling (age 15 and above) is another indicator of education. It varies across countries. For EU countries it is 8.95 years, the highest level compared to the mean years of schooling of MENA countries (6.2 years), Oil Exporter countries (8.04 years) and OPEC countries (5.47 years).

L. Viehoff considers that migration is a central issue for education. School leavers without a formal secondary school level qualification is high in OECD countries: In 14 of 27 OECD countries the share of young students leaving school without formal qualification (secondary II school level) reaches from $10 \%$ up to $33 \%$. Education reinforces existing social inequalities with children from migrational backgrounds at the end of the scale. In Germany e.g. $40 \%$ of children from migration families do not receive a secondary II level qualification.

Davis S. and Botkin J. (1997) concluded that the development of knowledge-based business reflects an even larger transformation occurring in our society. Education is no longer focused on the student years but is considered a lifelong pursuit. In knowledge economies, the rapid pace of technological change means that learning must be constant and that education must be updated throughout one' working life. Business, more than government, is instituting the changes that are required for the emerging knowledge-based 
Dependent variable School life expectancy

Method LOGARITH

Multiple R

, 72641

$\mathrm{R}$ Square

, 52767

Adjusted R Square

, 50713

Standard Error

, 80187

Analysis of Variance:

$$
\text { DF Sum of Squares Mean Square }
$$

Regression

$$
1
$$

$$
16,521470
$$

$$
16,521470
$$

$\mathrm{F}=\quad 25,69425 \quad$ Signif $\mathrm{F}=, 0000$

$$
, 643003
$$

Variables in the Equation

$\begin{array}{llllll}\text { Variable } & \text { B } & \text { SE B } & \text { Beta } & \text { T } & \text { Sig T }\end{array}$

$\begin{array}{lrcrrr}\text { GDP } & 1,926650 & , 38008 & , 726406 & 5,069 & , 0000 \\ \text { (Constant) } & -3,611531 & 3,782338 & & -, 955 & , 3496\end{array}$

School life expectancy

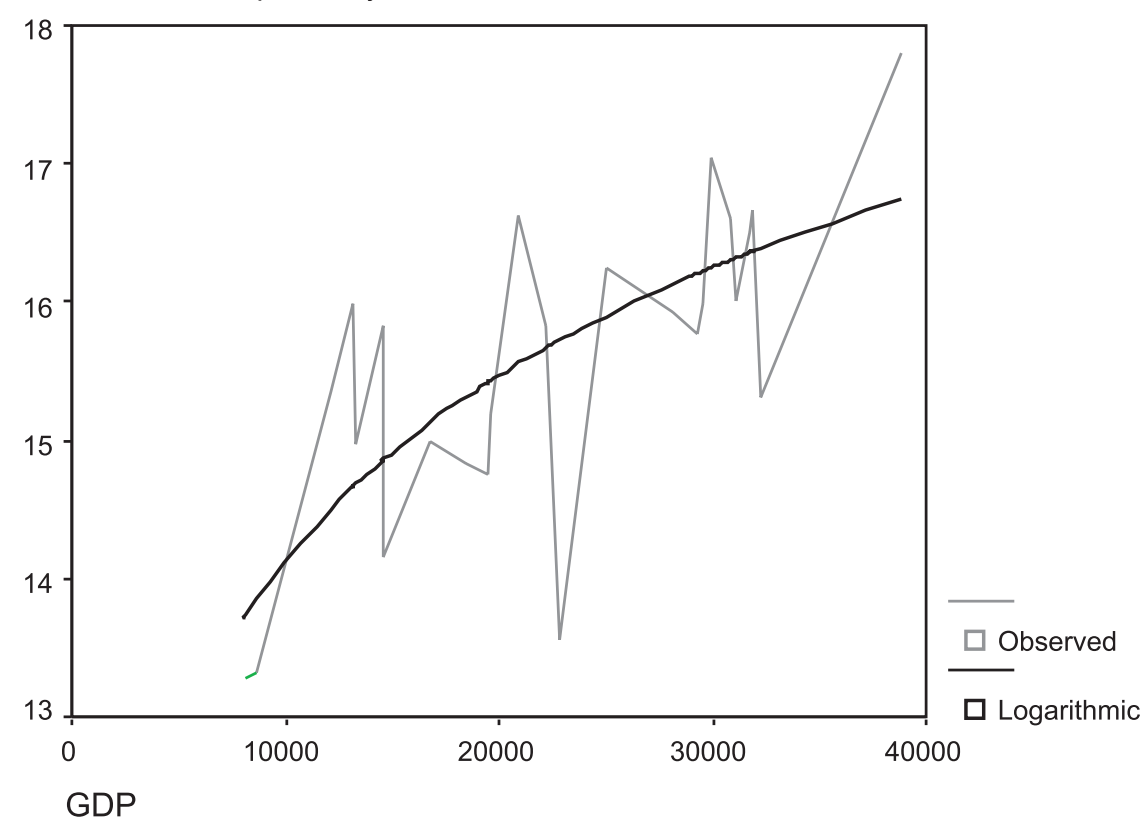


Method LOGARITH

Multiple R , 42133

R Square

, 17752

Adjusted R Square

14176

Standard Error

1,05814

Analysis of Variance:

DF Sum of Squares Mean Square

Regression $\quad 1 \quad 5,558132 \quad 5,5581317$

Residuals $23 \quad 25,752396 \quad 1,1196694$

$F=\quad 4,96408 \quad$ Signif $F=, 0359$

Variables in the Equation

$\begin{array}{llllll}\text { Variable } & B & \text { SE B } & \text { Beta } & \text { T } & \text { Sig T }\end{array}$

$\begin{array}{lrrrrr}\text { PSE(\%of GDP) } & 2,254724 & 1,011985 & , 421327 & 2,228 & , 0359 \\ \text { (Constant) } & 11,791033 & 1,697550 & & 6,946 & , 0000\end{array}$

School life expectancy (years).

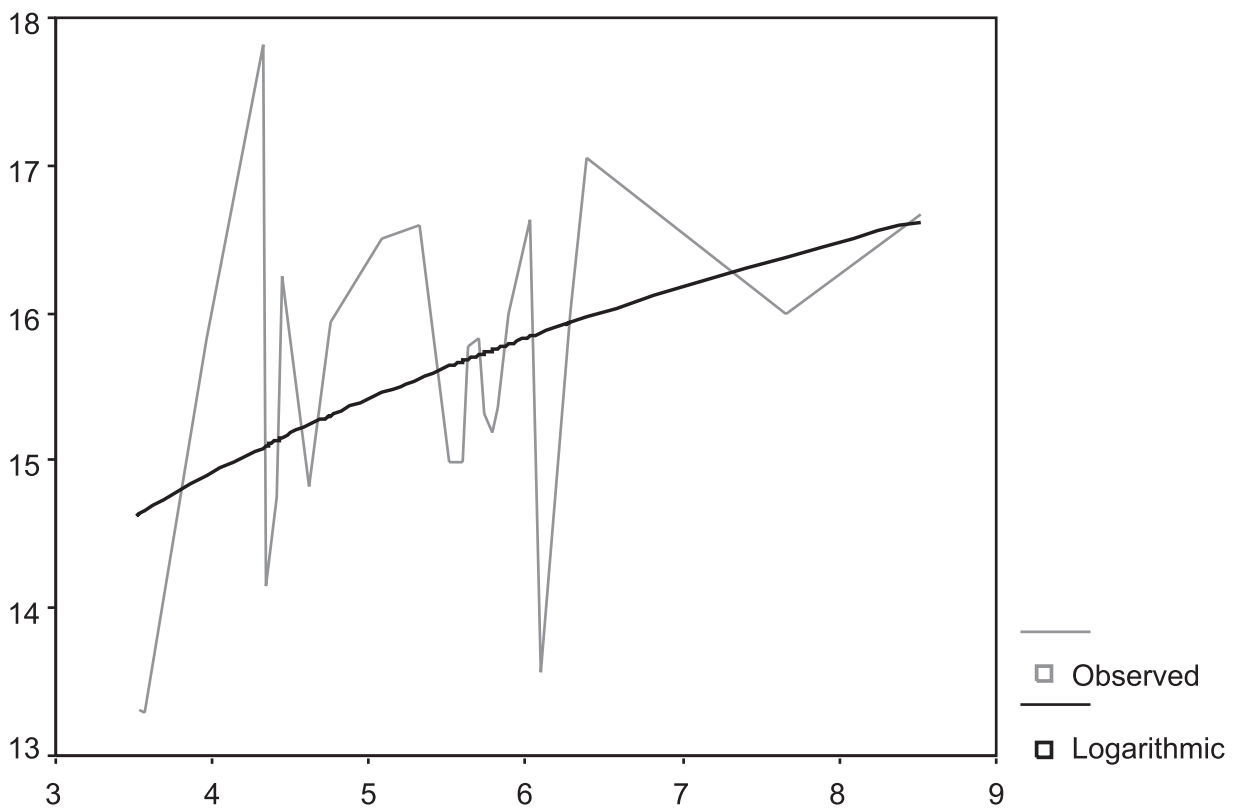

Public spending on education, total (\% of GDP) 
economy. And over the next few decades, the private sector will come to eclipse the public sector as our predominant educational institution.

\section{References}

Stan D., Botkin J., The Coming of Knowledge-Based Business, Harvard Business Review (94505), 1997. van den Berg G., Gorter C., Job Search and Commuting Time, Journal of Business\&Economics Statistics, 15(2), 1997.

van Dijk J., de Grip A., Institutions and Regional Labor Markets in The Netherlands, 1998.

Harris J., Todaro M., Migration, Unemployment and Development: two sector analysis, American Economic Review, March 1970, 15(1).

Nekkers G., van Eijs P., de Grip A., Diephuis B., Regional Supply-Demand Discrepancies: A Training Perspective, Maastricht University, Maastricht 2000.

http://devdata.worldbank.org/edstats/query/default.htm

\section{Zarządzanie edukacją w społeczeństwie opartym na wiedzy}

\section{Streszczenie}

Europa wdraża i rozwija zasady społeczeństwa opartego na wiedzy. Oznacza to przechodzenie od gospodarki opartej na tradycyjnych czynnikach produkcji (ziemia, praca, kapitał) do gospodarki, w której głównymi komponentami sq informacja i wiedza. Taki rozwój socjoekonomiczny i technologiczny ma istotny wpływ na rynek pracy oraz edukacji. W artykule analizowane sq osiagnięcia systemów edukacji oraz współzależności między edukacja i dobrobytem. 